\section{Nutrient Accumulation and Flower Bud Formation Affected by the Time of Terminal Bud Set on Water Sprouts of Persimmon}

\author{
Seong-Tae Choi ${ }^{1}$ and Doo-Sang Park \\ Sweet Persimmon Research Institute, Gyeongnam Agricultural Research \\ and Extension Services, Gimhae, Gyeongnam 621-802, Republic of Korea
}

\author{
Seong-Mo Kang \\ Department of Horticulture, Institute of Agriculture and Life Sciences, \\ Gyeongsang National University, Jinju, Gyeongnam 660-701, Republic of \\ Korea
}

Additional index words. Diospyros kaki, flower bud differentiation, flower primordia, mother branch

\begin{abstract}
Heavy pruning to lower tree height of persimmon results in excessive production of water sprouts and reduced yield. This experiment was conducted on 'Fuyu' (Diospyros kaki) trees to assess if the time for terminal bud set of water sprouts affected flower bud formation. Some sprouts were not pruned to serve as fruiting branches for the next season. Thirty to 40 water sprouts were tagged in 2005 and 2006, the growth of which stopped from mid-June to late August. The later terminal buds set, the lower the percent dry weight in the apical $10 \mathrm{~cm}$. The apical segments of sprouts that continued to grow to mid- to late August were characterized by low soluble sugars, starch, and inorganic elements such as nitrogen $(\mathrm{N})$, phosphorus $(\mathrm{P})$, potassium $(\mathrm{K})$, calcium $(\mathrm{Ca})$, and magnesium $(\mathrm{Mg})$ compared with those that set terminal buds earlier. The number of flower buds from the water sprouts that set terminal buds by early August the previous year bore more than 12 flower buds the next year, whereas those that grew to mid- to late August bore fewer than three. It was concluded that water sprouts could be used as fruiting branches for the next year as long as terminal buds set by early August, thereby alleviating yield reductions that come with heavy pruning.
\end{abstract}

Many persimmon growers in Korea prune trees to less than $3 \mathrm{~m}$ in height to improve light penetration into the canopy and to save labor costs. However, heavy pruning can cause excessive production of water sprouts, which are mostly removed when summer-pruned. Heavy pruning also results in the loss of a significant proportion of 1-year-old shoots, commonly called "mother branches" in persimmon, to bear fruiting shoots the next season so that yield reduction may be unavoidable.

Instead of pruning all water sprouts, attempts have been made to use them as mother branches in commercial orchards to make up for the yield reduction as well as to control tree vigor. For such an attempt to be successful, it is required for water sprouts to set terminal buds early enough to allow flower primordia to form in the buds. The terminal and several lateral buds near the apex on the mother branch can contain flower primordia (George et al., 1997; Harada, 1984). Two major problems

\footnotetext{
Received for publication 14 July 2010. Accepted for publication 29 Dec. 2010.

We gratefully acknowledge the financial support provided by the Rural Development Administration, Republic of Korea.

${ }^{1}$ To whom reprint requests should be addressed; e-mail stchoi1234@korea.kr.
}

exist in the use of water sprout as mother branches: flower primordia are not differentiated if they grow late and their early removal causes excessive budbreak of dormant buds. Bending the shoots inhibits growth while promoting flower bud initiation in persimmon (George et al., 1997) and apple (Jackson and Sweet, 1972; Mika, 1969).

Flower bud initiation of 'Fuyu' persimmon begins in mid-July in Korea (Rhee, 1975; Rhee and Ko, 1973). Initiation is influenced by environmental factors (George et al., 1997; Moon and Moon, 2001; Rhee, 1975), cultivar (Hasegawa et al., 2003), fruit load (Forshey and Elfving, 1989; Luckwill, 1974; Wünsche and Ferguson, 2005), and nutrient status of the shoot or a whole tree (Akira and Sadao, 1998; Buban and Faust, 1982; Choi et al., 2009b; Harada, 1984; Kishimoto, 1963; Rhee, 1975; Sobajima et al., 1968). However, flower bud initiation begins only after the terminal bud sets on current shoots in persimmon (George et al., 1997; Harada, 1984). Those shoots ending growth early in the season have a greater ability to differentiate flower buds than those ending late in the growing season, like in apple trees (Buban and Faust, 1982; Forshey and Elfving, 1989; Wilkie et al., 2008).

Because water sprouts on vigorous trees continue their extension growth until September, it has been assumed that their ability to differentiate flower buds may be widely varied depending on the time of terminal bud set. This experiment was conducted to assess the influence of the time for terminal bud set of water sprouts on the accumulation of carbohydrates and inorganic elements and flower bud formation for the next year.

\section{Materials and Methods}

Tree management. The experiment was conducted from 2005 to 2007 in 11- to 13year-old 'Fuyu' (Diospyros kaki) orchards located in Gimhae, Korea. Trees were planted at $3 \times 6-\mathrm{m}$ spacing and trained to a modified leader type. Trees received fertilization and trickle irrigation based on the standard recommendations (Rural Development Administration, 2004). Flower buds were thinned in early May to one or two per shoot before flowering. After the June drop, the leaf-fruit ratio was adjusted to $\approx 20$ by fruit thinning to maintain the recommended level of fruit load (Rural Development Administration, 2004). Tree management included routine chemical sprays to control diseases and pests. Because the trees were heavily pruned before budbreak to lower their height in 2005 and 2006, many upright water sprouts were produced.

Tagging, sampling, and measurement. Water sprouts occurred mainly on branches older than 3 years from May to June, and growth stopped when terminal buds set from June through August. Thirty and 40 water sprouts that had set the terminal buds were tagged at six different times in 2005 and 2006: midJune, mid-July, late July, early August, midAugust, and late August. Shoot length was measured on 31 Aug. Because persimmon only bear flower primordia in several later buds near the apex on the current season's shoots, 10 apical $10-\mathrm{cm}$ segments were sampled on 31 Aug. from the tagged sprouts. The sprout segments were divided into leaves and shoots for further analysis. Fresh weight of the segments was determined. SPAD value, which estimates chlorophyll content of the leaves, was measured with a chlorophyll meter (SPAD-502; Minolta Camera Co., Tokyo, Japan) and leaf area with a leaf area meter (Li-3100c; LI-COR, Lincoln, NE). The samples were dried at $80{ }^{\circ} \mathrm{C}$ for $48 \mathrm{~h}$ to determine dry weight (DW). Specific leaf weight (SLW) was calculated by dividing DW by leaf area.

The rest of the tagged sprouts was kept unpruned until each May of the next years to determine the number of shoots and flower buds. Approximately 3 weeks before flowering on 2 May 2006 and 2007, current and fruiting shoots and flower buds were counted from the 20 and 30 water sprouts tagged in the summer of 2005 and 2006, respectively.

Nutrient analysis. The dried leaf and shoot samples were ground with a Wiley mill (3383L10; Thomas Scientific, Swedesboro, NJ) equipped with a 20 -mesh screen to analyze carbohydrates and inorganic elements. This analysis was conducted to assess the effect of the time for terminal bud set of water sprouts on nutrient accumulation in the shoot apex. 
Carbohydrates were determined after extraction of anthrone-positive soluble sugars and hydrolysis of ethanol-insoluble starch fraction as described previously (Choi et al., 2009a; McCready et al., 1950). Glucose was the standard sugar used for determination of carbohydrates. To analyze inorganic elements, the sample was digested with $\mathrm{HClO}_{4}$ and $\mathrm{H}_{2} \mathrm{SO}_{4}$ on a heating block; the Kjeldahl method (Nelson and Sommers, 1973) was used for $\mathrm{N}$, vanadate method for $\mathrm{P}$, and atomic absorption for $\mathrm{K}, \mathrm{Ca}$, and $\mathrm{Mg}$ (Motsara and Roy, 2008). Nutrient contents per square centimeter leaf or per $10-\mathrm{cm}$ apical segment of sprouts are presented.

Statistical analysis. The experiments were designed in a completely randomized design with five replicates for each treatment and the data were collected from water sprouts of five trees per replication. Statistical analysis was performed using SAS software (SAS Institute, Inc., Cary, NC). Differences among the treatment means were determined using Duncan's multiple range test $(P \leq 0.05)$.

\section{Results and Discussion}

Growth of water sprout and bud development. Water sprouts were longer with later terminal bud set (Table 1). However, the lateness in the time of terminal bud set did not necessarily mean that those sprouts had a longer period of time to grow; the sprouts started to grow sometime in May through June, and those that started to grow later continued to grow later. In the apical $10-\mathrm{cm}$ segment of water sprouts in which flower primordia were differentiated, leaf area, SPAD value, leaf DW, and SLW gradually declined with later terminal bud set. More than a threefold difference was noted in the DW between the sprouts that had stopped growing by midJune and by late August. DW decreased from $1.22 \mathrm{~g}$ and $1.54 \mathrm{~g}$ at the mid-June to $0.40 \mathrm{~g}$ and $0.26 \mathrm{~g}$ at the late August bud set in 2005 and 2006 , respectively. DW ratio of those segments decreased from $41.9 \%$ to $21.5 \%$ in 2005 and $20.3 \%$ in 2006. Significant decreases in DW of the sprouts that had continued to grow late were an indication of their low maturity; the shoots were greener and the terminal buds were smaller (Fig. 1). Considering the growth of water sprouts, it appeared that the stage of bud development was not mature enough for flower bud initiation in those water sprouts that stopped their extension growth later than midAugust. Induction of flower buds is governed by hormonal balance, especially by the level of gibberellins (Luckwill, 1974; Sedgley, 1990). In this study, we sampled the apical $10-\mathrm{cm}$ segment of the sprouts where flower primordia are differentiated. The physiological age of the leaves near the apex varies widely depending on the time of terminal bud set. Environmental conditions, including light and temperature during late summer (Buban and Faust, 1982; Jackson and Sweet, 1972; Sedgley, 1990), may be another factor causing hormonal changes that affect flower bud formation.

Carbohydrates and inorganic elements in the apical segment. Carbohydrates per square
Table 1. Length of a water sprout that set the terminal bud at different times and the characteristics of its apical 10 -cm segment. ${ }^{2}$

\begin{tabular}{|c|c|c|c|c|c|c|c|}
\hline \multirow[b]{2}{*}{$\begin{array}{l}\text { Terminal } \\
\text { bud set }\end{array}$} & \multirow{2}{*}{$\begin{array}{c}\text { Length of } \\
\text { water sprout } \\
(\mathrm{cm})\end{array}$} & \multicolumn{4}{|c|}{ Leaf } & \multicolumn{2}{|c|}{ Shoot } \\
\hline & & $\begin{array}{c}\text { Area } \\
\left(\mathrm{cm}^{2} / \text { leaf }\right)\end{array}$ & $\begin{array}{l}\text { SPAD } \\
\text { value }\end{array}$ & $\begin{array}{c}\text { DW } \\
\text { (g/leaf) }\end{array}$ & $\begin{array}{c}\mathrm{SLW} \\
\left(\mathrm{mg} \cdot \mathrm{cm}^{-2}\right)\end{array}$ & $\begin{array}{c}\text { DW } \\
(\mathrm{g})\end{array}$ & $\begin{array}{c}\text { DW ratio } \\
(\%)\end{array}$ \\
\hline \multicolumn{8}{|c|}{2005} \\
\hline Mid-June & $55 \mathrm{c}^{\mathrm{y}}$ & $80 \mathrm{~b}$ & $48.2 \mathrm{a}$ & $1.07 \mathrm{a}$ & $13.3 \mathrm{a}$ & $1.22 \mathrm{a}$ & $41.9 \mathrm{a}$ \\
\hline Mid-July & $73 \mathrm{~b}$ & $98 \mathrm{a}$ & $47.5 \mathrm{a}$ & $1.16 \mathrm{a}$ & $11.9 \mathrm{~b}$ & $1.31 \mathrm{a}$ & $44.2 \mathrm{a}$ \\
\hline Late July & $106 \mathrm{a}$ & $93 \mathrm{ab}$ & $44.6 \mathrm{ab}$ & $1.05 \mathrm{a}$ & $11.3 \mathrm{~b}$ & $1.09 \mathrm{ab}$ & $35.6 \mathrm{~b}$ \\
\hline Early Aug. & $123 \mathrm{a}$ & $90 \mathrm{ab}$ & $40.8 \mathrm{~b}$ & $0.98 \mathrm{a}$ & $10.9 \mathrm{~b}$ & $0.93 \mathrm{~b}$ & $31.5 \mathrm{c}$ \\
\hline Mid-Aug. & $107 \mathrm{a}$ & $59 \mathrm{c}$ & $31.3 \mathrm{c}$ & $0.53 \mathrm{~b}$ & $8.9 \mathrm{c}$ & $0.41 \mathrm{c}$ & $30.4 \mathrm{c}$ \\
\hline Late Aug. & $114 \mathrm{a}$ & $39 \mathrm{~d}$ & $24.7 \mathrm{~d}$ & $0.32 \mathrm{c}$ & $8.1 \mathrm{c}$ & $0.40 \mathrm{c}$ & $21.5 \mathrm{~d}$ \\
\hline \multicolumn{8}{|c|}{2006} \\
\hline Mid-June & $62 \mathrm{~b}$ & $86 a$ & $53.9 \mathrm{a}$ & $1.08 \mathrm{a}$ & $12.6 \mathrm{a}$ & $1.54 \mathrm{a}$ & $41.9 \mathrm{a}$ \\
\hline Mid-July & $72 \mathrm{~b}$ & $79 \mathrm{a}$ & $51.1 \mathrm{a}$ & $0.93 \mathrm{ab}$ & $11.8 \mathrm{ab}$ & $1.32 \mathrm{~b}$ & $40.1 \mathrm{a}$ \\
\hline Late July & $68 \mathrm{~b}$ & $78 \mathrm{a}$ & $52.0 \mathrm{a}$ & $0.86 \mathrm{bc}$ & $11.0 \mathrm{~b}$ & $1.19 \mathrm{~b}$ & $35.9 \mathrm{~b}$ \\
\hline Early Aug. & $71 \mathrm{~b}$ & $74 \mathrm{a}$ & $41.9 \mathrm{a}$ & $0.75 \mathrm{c}$ & $10.1 \mathrm{c}$ & $0.94 \mathrm{c}$ & $33.2 \mathrm{c}$ \\
\hline Mid-Aug. & $95 \mathrm{a}$ & $50 \mathrm{~b}$ & $28.5 \mathrm{~b}$ & $0.33 \mathrm{~d}$ & $6.5 \mathrm{~d}$ & $0.33 \mathrm{~d}$ & $21.3 \mathrm{~d}$ \\
\hline Late Aug. & $92 \mathrm{a}$ & $19 \mathrm{c}$ & $23.7 \mathrm{~b}$ & $0.13 \mathrm{e}$ & $6.8 \mathrm{~d}$ & $0.26 \mathrm{~d}$ & $20.3 \mathrm{~d}$ \\
\hline
\end{tabular}

${ }^{2}$ The segments were sampled on 31 Aug. and the characteristics were measured from all of four to seven leaves on the shoot.

yean values in each column and year with the same letter are not significantly different by Duncan's multiple range test at $P \leq 0.05$.

$\mathrm{DW}=$ dry weight.

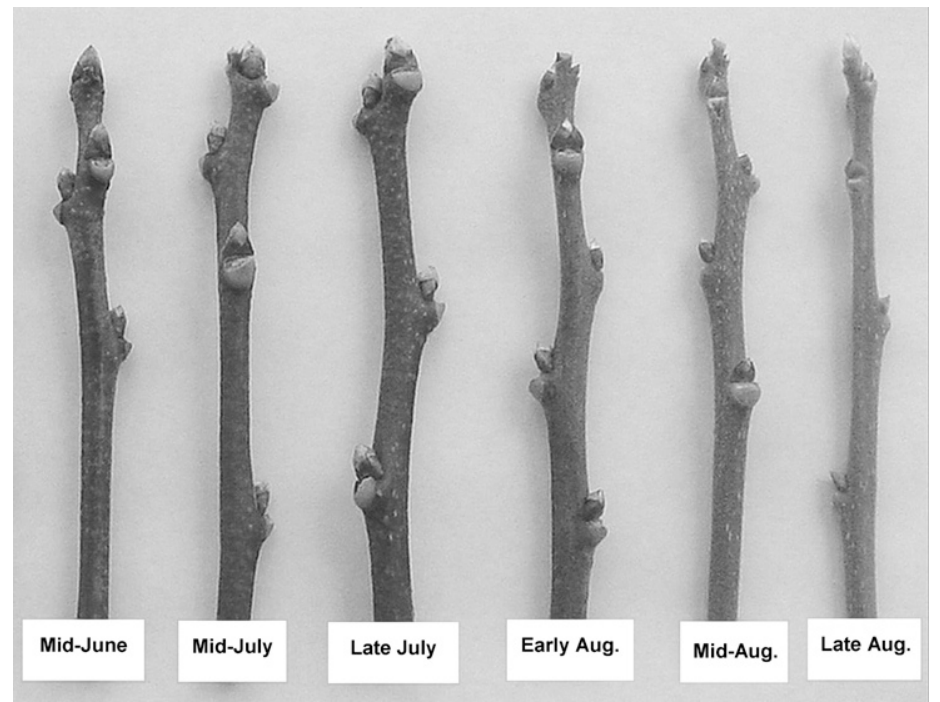

Fig. 1. Apical $10-\mathrm{cm}$ segments of water sprouts that set the terminal buds at different times. All the segments were taken on 31 Aug.

Table 2. Leaf and shoot carbohydrates in the apical 10-cm segment of a water sprout that set the terminal bud at different times. ${ }^{z}$

\begin{tabular}{|c|c|c|c|c|}
\hline \multirow[b]{3}{*}{ Terminal bud set } & \multicolumn{2}{|c|}{ Leaf } & \multicolumn{2}{|c|}{ Shoot } \\
\hline & Soluble sugars & Starch & Soluble sugars & Starch \\
\hline & \multicolumn{2}{|c|}{$\left(\mathrm{mg} \cdot \mathrm{cm}^{-2}\right.$ leaf disk $)$} & \multicolumn{2}{|c|}{ (mg/apical 10-cm shoot) } \\
\hline \multicolumn{5}{|c|}{2005} \\
\hline Mid-June & $0.86 \mathrm{a}^{\mathrm{y}}$ & $0.56 \mathrm{a}$ & $45.5 \mathrm{a}$ & $44.3 \mathrm{~b}$ \\
\hline Mid-July & $0.73 \mathrm{~b}$ & $0.31 \mathrm{~d}$ & $50.2 \mathrm{a}$ & $64.9 \mathrm{a}$ \\
\hline Late July & $0.72 \mathrm{~b}$ & $0.38 \mathrm{c}$ & $40.1 \mathrm{~b}$ & $26.2 \mathrm{c}$ \\
\hline Early Aug. & $0.74 \mathrm{~b}$ & $0.41 \mathrm{c}$ & $30.8 \mathrm{c}$ & $17.7 \mathrm{~d}$ \\
\hline Mid-Aug. & $0.64 \mathrm{~b}$ & $0.48 \mathrm{~b}$ & $19.5 \mathrm{~d}$ & $7.4 \mathrm{e}$ \\
\hline Late Aug. & $0.40 \mathrm{c}$ & $0.30 \mathrm{~d}$ & $19.1 \mathrm{~d}$ & $8.4 \mathrm{e}$ \\
\hline \multicolumn{5}{|c|}{2006} \\
\hline Mid-June & $0.84 \mathrm{a}$ & $0.31 \mathrm{a}$ & $77.2 \mathrm{a}$ & $45.9 \mathrm{a}$ \\
\hline Mid-July & $0.85 \mathrm{a}$ & $0.31 \mathrm{a}$ & $66.0 \mathrm{~b}$ & $36.4 \mathrm{~b}$ \\
\hline Late July & $0.77 \mathrm{ab}$ & $0.30 \mathrm{a}$ & $58.8 \mathrm{~b}$ & $27.8 \mathrm{c}$ \\
\hline Early Aug. & $0.72 \mathrm{~b}$ & $0.27 \mathrm{~b}$ & $48.0 \mathrm{c}$ & $22.4 \mathrm{c}$ \\
\hline Mid-Aug. & $0.41 \mathrm{c}$ & $0.20 \mathrm{c}$ & $15.7 \mathrm{~d}$ & $7.3 \mathrm{~d}$ \\
\hline Late Aug. & $0.20 \mathrm{~d}$ & $0.12 \mathrm{~d}$ & $12.1 \mathrm{~d}$ & $6.2 \mathrm{~d}$ \\
\hline
\end{tabular}

${ }^{2}$ The segments were sampled on 31 Aug.

${ }^{\mathrm{y}}$ Mean values in each column and year with the same letter are not significantly different by Duncan's multiple range test at $P \leq 0.05$. 
Table 3. Leaf and shoot inorganic elements in the apical 10-cm segment of a water sprout that set the terminal bud at different times. ${ }^{\mathrm{z}}$

\begin{tabular}{|c|c|c|c|c|c|c|c|c|c|c|}
\hline \multirow[b]{3}{*}{ Terminal bud set } & \multicolumn{5}{|c|}{ Leaf } & \multicolumn{5}{|c|}{ Shoot } \\
\hline & Nitrogen & Phosphorus & Potassium & Calcium & Magnesium & Nitrogen & Phosphorus & Potassium & Calcium & Magnesium \\
\hline & \multicolumn{5}{|c|}{$\left(\mathrm{mg} \cdot \mathrm{cm}^{-2}\right.$ leaf disk $)$} & \multicolumn{5}{|c|}{ (mg/apical 10-cm shoot) } \\
\hline & & & & & 2005 & & & & & \\
\hline Mid-June & $0.25 \mathrm{a}^{\mathrm{y}}$ & $0.016 \mathrm{c}$ & $0.35 \mathrm{a}$ & $0.101 \mathrm{a}$ & $0.046 \mathrm{a}$ & $10.23 \mathrm{a}$ & $2.50 \mathrm{a}$ & $13.28 \mathrm{a}$ & $8.83 \mathrm{a}$ & $1.87 \mathrm{~b}$ \\
\hline Mid-July & $0.21 \mathrm{~b}$ & $0.015 \mathrm{~d}$ & $0.34 \mathrm{a}$ & $0.093 \mathrm{ab}$ & $0.040 \mathrm{~b}$ & $9.69 \mathrm{a}$ & $2.30 \mathrm{~b}$ & $13.30 \mathrm{a}$ & $9.44 \mathrm{a}$ & $2.25 \mathrm{a}$ \\
\hline Late July & $0.21 \mathrm{~b}$ & $0.015 \mathrm{~d}$ & $0.30 \mathrm{~b}$ & $0.080 \mathrm{bc}$ & $0.032 \mathrm{c}$ & $10.64 \mathrm{a}$ & $2.20 \mathrm{~b}$ & $14.25 \mathrm{a}$ & $7.13 \mathrm{~b}$ & $1.88 \mathrm{~b}$ \\
\hline Early Aug. & $0.21 \mathrm{~b}$ & $0.018 \mathrm{~b}$ & $0.26 \mathrm{c}$ & $0.071 \mathrm{c}$ & $0.025 \mathrm{~d}$ & $10.31 \mathrm{a}$ & $2.43 \mathrm{a}$ & $13.98 \mathrm{a}$ & $6.17 \mathrm{~b}$ & $1.87 \mathrm{~b}$ \\
\hline Mid-Aug. & $0.14 \mathrm{c}$ & $0.015 \mathrm{~d}$ & $0.24 \mathrm{~d}$ & $0.051 \mathrm{~d}$ & $0.020 \mathrm{e}$ & $3.45 \mathrm{c}$ & $1.01 \mathrm{c}$ & $7.14 \mathrm{c}$ & $2.70 \mathrm{c}$ & $0.90 \mathrm{c}$ \\
\hline \multirow[t]{2}{*}{ Late Aug. } & $0.14 \mathrm{c}$ & $0.019 \mathrm{a}$ & $0.20 \mathrm{e}$ & $0.046 \mathrm{~d}$ & $0.019 \mathrm{e}$ & $5.29 \mathrm{~b}$ & $1.04 \mathrm{c}$ & $10.13 \mathrm{~b}$ & $2.57 \mathrm{c}$ & $0.97 \mathrm{c}$ \\
\hline & & & & & 2006 & & & & & \\
\hline Mid-June & $0.24 \mathrm{a}$ & $0.018 \mathrm{~b}$ & $0.29 \mathrm{a}$ & $0.093 \mathrm{a}$ & $0.044 \mathrm{a}$ & $14.9 \mathrm{a}$ & $3.36 \mathrm{a}$ & $16.8 \mathrm{a}$ & $9.43 \mathrm{a}$ & $3.17 \mathrm{a}$ \\
\hline Mid-July & $0.21 \mathrm{~b}$ & $0.017 \mathrm{bc}$ & $0.27 \mathrm{a}$ & $0.081 \mathrm{~b}$ & $0.043 \mathrm{a}$ & $12.0 \mathrm{~b}$ & $3.01 \mathrm{ab}$ & $15.2 \mathrm{a}$ & $8.86 \mathrm{a}$ & $2.72 \mathrm{ab}$ \\
\hline Late July & $0.21 \mathrm{~b}$ & $0.016 \mathrm{~cd}$ & $0.24 \mathrm{~b}$ & $0.068 \mathrm{c}$ & $0.037 \mathrm{~b}$ & $12.6 \mathrm{~b}$ & $2.79 \mathrm{~b}$ & $14.7 \mathrm{ab}$ & $7.10 \mathrm{~b}$ & $2.33 \mathrm{~b}$ \\
\hline Early Aug. & $0.19 \mathrm{c}$ & $0.015 \mathrm{~d}$ & $0.22 \mathrm{c}$ & $0.063 \mathrm{c}$ & $0.031 \mathrm{c}$ & $9.9 \mathrm{c}$ & $2.23 \mathrm{c}$ & $12.6 \mathrm{~b}$ & $4.89 \mathrm{c}$ & $1.86 \mathrm{c}$ \\
\hline Mid-Aug. & $0.12 \mathrm{e}$ & $0.017 \mathrm{bc}$ & $0.16 \mathrm{~d}$ & $0.025 \mathrm{~d}$ & $0.018 \mathrm{~d}$ & $3.5 \mathrm{~d}$ & $0.79 \mathrm{~d}$ & $5.3 \mathrm{c}$ & $1.63 \mathrm{~d}$ & $0.59 \mathrm{~d}$ \\
\hline Late Aug. & $0.14 \mathrm{~d}$ & $0.023 \mathrm{a}$ & $0.15 \mathrm{~d}$ & $0.014 \mathrm{e}$ & $0.018 \mathrm{~d}$ & $3.8 \mathrm{~d}$ & $0.70 \mathrm{~d}$ & $5.2 \mathrm{c}$ & $0.60 \mathrm{~d}$ & $0.51 \mathrm{~d}$ \\
\hline
\end{tabular}

${ }^{\mathrm{z}}$ The segments were sampled on 31 Aug.

${ }^{y}$ Mean values in each column and year with the same letter are not significantly different by Duncan's multiple range test at $P \leq 0.05$.

centimeter leaf disk decreased significantly by late terminal bud set (Table 2). There was a 2.2 - to 4.2 -fold decrease in soluble sugars and a 1.9- to 2.6-fold decrease in starch between the mid-June and late August bud set in both years. Carbohydrate content in a shoot segment was significantly low with later terminal bud set. Soluble sugars decreased from $45.5 \mathrm{mg}$ and $77.2 \mathrm{mg}$ for the mid-June to $19.1 \mathrm{mg}$ and $12.1 \mathrm{mg}$ for the late August bud set in 2005 and 2006 , respectively. Starch in a shoot segment declined from $44.3 \mathrm{mg}$ and $45.9 \mathrm{mg}$ to $8.4 \mathrm{mg}$ and $6.2 \mathrm{mg}$, respectively, in the same comparison. The terminal bud set by the end of July or early August appeared critical with regard to the accumulation of carbohydrates in the apical segments. The difference of carbohydrates might affect flower bud formation of water sprouts during the summer as documented from the girdling experiments that increased carbohydrate and led to faster floral initiation of fruit trees (George et al., 1997; Wilkie et al., 2008).

All the inorganic elements measured decreased with later terminal bud set except $P$ (Table 3). P remained high even at the late August bud set. The total amount of inorganic elements in an apical shoot segment was significantly higher when terminal bud was set by early August. There was more than a threefold difference between the mid-June and late August bud set in 2006, attributable mainly to the difference in their DWs (Table 1) rather than their concentrations.

Flower buds the next year. Table 4 shows the number of current shoots and flower buds in a water sprout tagged the previous year according to the time for their terminal bud set. The current shoots grown from the sprouts were the fewest for the mid-June and the most for the early August in 2005. However, the shoot number was the most at the mid-August bud set in 2006. Number of buds that grew the next year was determined largely by the length of water sprouts (Table 1). More than four current shoots bore flower buds in both years as long as terminal buds were set by early August the previous years. No current shoots bore flower buds at the late August bud set. Total number of

Table 4. Number of shoots and flower buds counted on 2 May the next years from the water sprouts that set the terminal buds at different times the previous years.

\begin{tabular}{|c|c|c|c|c|}
\hline \multirow[b]{2}{*}{ Terminal bud set } & \multicolumn{2}{|c|}{ No. of shoots per water sprout } & \multicolumn{2}{|c|}{ No. of flower buds per } \\
\hline & Total & Fruiting & Fruiting shoot & Water sprout \\
\hline \multicolumn{5}{|c|}{2006 (from water sprouts tagged in 2005) } \\
\hline Mid-June & $10 c^{z}$ & $4.8 \mathrm{~b}$ & $2.5 \mathrm{a}$ & $12 \mathrm{bc}$ \\
\hline Mid-July & $11 \mathrm{c}$ & $7.0 \mathrm{ab}$ & $2.4 \mathrm{a}$ & $17 \mathrm{ab}$ \\
\hline Late July & $16 \mathrm{~b}$ & $9.2 \mathrm{a}$ & $3.0 \mathrm{a}$ & $28 \mathrm{a}$ \\
\hline Early Aug. & $20 \mathrm{a}$ & $9.2 \mathrm{a}$ & $2.7 \mathrm{a}$ & $25 \mathrm{ab}$ \\
\hline Mid-Aug. & $11 \mathrm{c}$ & $0.9 \mathrm{c}$ & $1.1 \mathrm{~b}$ & $1 \mathrm{c}$ \\
\hline Late Aug. & $15 \mathrm{~b}$ & $0 \mathrm{c}$ & $0 \mathrm{c}$ & $0 \mathrm{c}$ \\
\hline \multicolumn{5}{|c|}{2007 (from water sprouts tagged in 2006) } \\
\hline Mid-June & $14 \mathrm{c}$ & $7.7 \mathrm{a}$ & $2.5 \mathrm{~b}$ & $19 \mathrm{ab}$ \\
\hline Mid-July & $16 \mathrm{bc}$ & $7.6 \mathrm{a}$ & $2.9 \mathrm{ab}$ & $22 \mathrm{a}$ \\
\hline Late July & $16 \mathrm{bc}$ & $7.5 \mathrm{a}$ & $3.2 \mathrm{a}$ & $24 \mathrm{a}$ \\
\hline Early Aug. & $17 \mathrm{~b}$ & $5.7 \mathrm{ab}$ & $2.3 \mathrm{~b}$ & $13 \mathrm{~b}$ \\
\hline Mid-Aug. & $22 \mathrm{a}$ & $1.9 \mathrm{~b}$ & $1.6 \mathrm{c}$ & $3 \mathrm{c}$ \\
\hline Late Aug. & $16 \mathrm{bc}$ & $0 \mathrm{~b}$ & $0 \mathrm{~d}$ & $0 \mathrm{c}$ \\
\hline
\end{tabular}

$\overline{{ }^{\mathrm{z}} \text { Mean values in each column and year with the same letter are not significantly different by Duncan's }}$ multiple range test at $P \leq 0.05$.

flower buds born on a water sprout at the early August bud set was 25 in 2006 and 13 in 2007, the number of which was still too many to grow marketable fruits. Water sprouts differ from spring-grown normal shoots in terms of the time of their occurrence, their size, and vigor (Park et al., 2008). However, some of them could be used as mother branches. In addition to the time for terminal bud set, the length of water sprouts was another important factor as to how many flower buds would develop. Flower bud weight and fruit growth after adjusting the crop load the next year were not significantly correlated with the time of terminal bud set the previous year (data not shown).

Our data clearly indicated that few flower buds formed on sprouts grown after midAugust. Sobajima et al. (1968) documented that total carbohydrates as well as the carbon$\mathrm{N}$ ratio increased before flower bud formation of persimmon shoots. However, it was not certain whether a relationship existed between the concentrations, rather than total contents, of inorganic nutrients and carbohydrates in the $10-\mathrm{cm}$ segments and the number of flowers the next season. Notwithstanding, the number of flower buds the next year changed with nutri- ent contents in the apical segment of the sprout and the unit area of the leaves; they increased significantly with earlier bud set. Leaf carbohydrate content at the time of flower bud initiation was reported to be an important factor for determining the number and quality of persimmon flowers the next year (Akira and Sadao, 1998). The earlier the growth cessation of water sprouts, the more carbohydrates would accumulate in the leaves. If the sprouts continued to grow during the time of flower bud differentiation, they could remain vegetative accumulating insufficient nutrients in the apical segment. Low $\mathrm{N}$ in persimmon during summer resulted in reduced flower bud differentiation (Choi et al., 2009b).

In conclusion, number of flower buds on water sprouts increased with later terminal bud set up to early August. Retaining some of these sprouts during summer pruning should increase fruit yield the next year.

\section{Literature Cited}

Akira, O. and A. Sadao. 1998. Relationship between the number of flowers and the nutrient status of Japanese persimmon (Diospyros kaki L.) tree 
'Maekawa Jiro'. J. Jpn. Soc. Hort. Sci. 67:890896.

Buban, T. and M. Faust. 1982. Flower bud induction in apple trees: Internal control and differentiation. Hort. Rev. 4:174-203.

Choi, S.T., D.S. Park, Y.C. Cho, and S.M. Kang. 2009a. Effect of different degrees of local defoliation in 'Fuyu' persimmon on fruit and tree development in the current and following years. Hort. Environ. Biotechnol. 50:74-78.

Choi, S.T., D.S. Park, Y.C. Cho, and S.M. Kang. 2009b. Tree responses of 'Fuyu' persimmon to urea nitrogen applied at different times during the late season. Acta Hort. 833:307-312.

Forshey, C.G. and D.C. Elfving. 1989. The relationship between vegetative growth and fruiting in apple trees. Hort. Rev. 11:229-287.

George, A.P., A.D. Mowat, R.J. Collins, and M. Morley-Bunker. 1997. The pattern and control of reproductive development in non-astringent persimmon (Diospyros kaki L.): A review. Sci. Hort. 70:93-122.

Harada, H. 1984. Relationship between shoot growth, auxiliary bud development and flower initiation in Japanese persimmon. J. Jpn. Soc. Hort. Sci. 53:271-275.

Hasegawa, K., T. Fukuta, K. Nishio, and A. Kitajima. 2003. Male and female flower buds differentiation and development in Japanese persimmon 'Nishimurawase', 'Zenjimaru' and 'Taisyu'. Research Rep. Kochi Univ. Agr. Sci. 52:1-13.
Jackson, D.I. and G.B. Sweet. 1972. Flower initiation in temperate woody plants (a review based largely on the literature of conifers and deciduous fruit trees). Hort. Abstr. 42:9-25.

Kishimoto, O. 1963. Studies on the standard of fruit thinning in Japanese persimmons, Diospyros kaki LINN. f. J. Jpn. Soc. Hort. Sci. 32:168174.

Luckwill, L.C. 1974. A new look at the process of fruit bud formation in apple. Proc. 19th Int. Hort. Congr. 3:237-245.

McCready, R.M., J. Guggolz, V. Silviera, and H.S. Owens. 1950. Determination of starch and amylose in vegetables. Anal. Chem. 22:1156-1158.

Mika, A. 1969. Effects of shoot bending and pruning on growth and fruit bud formation in young apple trees. Hort. Res. 9:93-102.

Moon, D.Y. and D.K. Moon. 2001. Effect of long day treatment on growth and flower bud differentiation of persimmon (Diospyros kaki Thunb.) grown in heated plastic house. Korean J. Hort. Sci. Technol. 19:540-544.

Motsara, M.R. and R.N. Roy. 2008. Guide to laboratory establishment for plant nutrient analysis. FAO Fert. Plant Nutr. Bull. 19.

Nelson, D.W. and L.E. Sommers. 1973. Determination of total nitrogen in plant material. Agron. J. 65:109-112.

Park, D.S., S.T. Choi, S.C. Kim, and S.M. Kang. 2008. Yield, fruit quality, and branch extension of 'Fuyu' persimmon as affected by the length of bearing mother branches. Korean J. Hort. Sci. Technol. 26:101-105.

Rhee, Y.S. 1975. Study on the flower bud differentiation of main fruit trees in Korea - Studies on the effect of environmental factors and some cultural treatments on the differentiation of flower bud in certain fruit species in Korea. J. Korean Soc. Hort. Sci. 16:121-143.

Rhee, Y.S. and K.C. Ko. 1973. Study on the flower bud differentiation of main fruit trees in Korea-1. Study on the time of initiation of flower bud differentiation on leading fruit varieties in the localities of Korea. J. Korean Soc. Hort. Sci. 13:115-123.

Rural Development Administration. 2004. Cultural practices of fruit trees. National Institute of Horticultural \& Herbal Science, Suwon. Korea (South). 10 Dec. 2010. <http://www.nihhs.go. $\mathrm{kr} />$.

Sedgley, M. 1990. Flowering of deciduous perennial fruit crops. Hort. Rev. 12:223-264.

Sobajima, Y., M. Ishida, and Y. Yamamoto. 1968. Studies on the control of alternate bearing in Kaki trees: 1. Seasonal change of the nitrogen and carbohydrate contents in the current shoots. Sci. Rep. Kyoto Prefect. Univ. Agr. 19:1-5.

Wilkie, J.D., M. Sedgley, and T. Olesen. 2008 Regulation of floral initiation in horticultural trees. J. Expt. Bot. 59:3215-3228.

Wünsche, J.N. and I.B. Ferguson. 2005. Crop load interactions in apple. Hort. Rev. 31:231-290. 